\title{
Hepatic resection for hepatocellular carcinoma
}

\author{
Shun Yamaguchi", Taichiro Kosaka\#, Susumu Eguchi \\ Department of Surgery, Nagasaki University Graduate School of Biomedical Sciences, Nagasaki 8528102, Japan. \\ \#Authors contributed equally.
}

Correspondence to: Dr. Susumu Eguchi, Department of Surgery, Nagasaki University Graduate School of Biomedical Sciences, Sakamoto1-7-1, Nagasaki 8528102, Japan. E-mail: sueguchi@nagasaki-u.ac.jp

How to cite this article: Yamaguchi S, Kosaka T, Eguchi S. Hepatic resection for hepatocellular carcinoma. Hepatoma Res 2018;4:50. http://dx.doi.org/10.20517/2394-5079.2018.68

Received: 25 May 2018 First Decision: 16 Jul 2018 Revised: 31 Jul 2018 Accepted: 1 Aug 2018 Published: 22 Aug 2018

Science Editor: Guang-Wen Cao Copy Editor: Jun-Yao Li Production Editor: Cai-Hong Wang

\begin{abstract}
Hepatic resection has become the standard treatment of primary liver cancer. Indications for hepatic resection in patients with hepatocellular carcinoma (HCC) vary greatly between Japan and other countries because the clinical practice guidelines for HCC defined by the Japan Society of Hepatology differ from the EASL-EORTC clinical practice guidelines. Hepatic resection is not recommended as a treatment for the patients at Barcelona Clinic Liver Cancer (BCLC) stage B. Otherwise, there are many surgeons/clinicians who believe that not all HCC patients at BCLC stage B should be excluded from an indication for hepatectomy because many reports showed good prognosis after hepatic resection for HCC patients over BCLC stage B. The survival rate is expected to increase with better outcomes of hepatectomy in the future. This paper has described indications for hepatectomy for patients with HCC through comparison of domestic guidelines with overseas guidelines, focusing on their differences.
\end{abstract}

Keywords: Hepatic resection, hepatocellular carcinoma, guidelines

\section{INTRODUCTION}

Indications for surgical resection in patients with hepatocellular carcinoma (HCC) vary greatly between Japan and other countries. This is because many Japanese medical institutions decide on the indication based on the clinical practice guidelines for HCC defined by the Japan Society of Hepatology $y^{[1]}$, which differs from the EASL-EORTC clinical practice guidelines ${ }^{[2]}$ in terms of the HCC stage, and the hepatic reserve as an indication for hepatectomy. This paper compares both guidelines in terms of surgical resection for hepatocellular carcinoma.

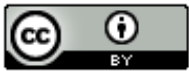

(C) The Author(s) 2018. Open Access This article is licensed under a Creative Commons Attribution 4.0 International License (https://creativecommons.org/licenses/by/4.0/), which permits unrestricted use, sharing, adaptation, distribution and reproduction in any medium or format, for any purpose, even commercially, as long as you give appropriate credit to the original author(s) and the source, provide a link to the Creative Commons license, and indicate if changes were made.

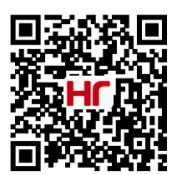




\section{EVALUATION OF PREOPERATIVE HEPATIC RESERVE}

Liver carcinoma is often caused by viral hepatitis, alcoholic hepatitis, or non-alcoholic steatohepatitis (NASH), and when hepatectomy is performed it is necessary to pay attention to postoperative decrease in residual liver function as well as curability of the cancer.

The Child-Pugh score ${ }^{[3]}$ is used worldwide to assess preoperative hepatic reserve. The EASL-EORTC clinical practice guidelines ${ }^{[2]}$ usually exclude Child-Pugh B and C patients and even Child-Pugh A patients with increased portal blood pressure or high levels of bilirubin from indications for hepatectomy. The Japanese guidelines also recommend a treatment decision based on the Child-Pugh score, and hepatectomy in ChildPugh A and B patients and liver transplant in Child-Pugh C patients have shown favorable results ${ }^{[4,5]}$. Importantly, an indication for liver transplant in Child-Pugh C patients is because liver transplants performed in Japan are usually living-donor liver transplantation due to the scarcity of brain-dead donors, and patients undergoing liver transplantation have developed liver cancer mostly caused by decompensated cirrhosis.

The evaluation scale often used in Japan for hepatectomy is assessment of liver damage under the general rules for the clinical and pathological study of primary liver cancer calculated by an indocyanine green retention rate after $15 \mathrm{~min}$ (ICG15), ascites, serum bilirubin level, serum albumin level, and prothrombin activity ${ }^{[6]}$. Actually, many reports showed that the ICG load test was a significant predictor of postoperative death $^{[7,8]}$, and the Makuuchi criteria ${ }^{[9]}$ for safe hepatic resection, which are used as a reference for hepatectomy in many institutions, also base the advisability of hepatectomy on bilirubin level, ICG15, and ascites as well as the resectable limits. There was little mortality in patients undergoing hepatectomy in compliance with these criteria. Based on what was mentioned above, the ICG load test is considered likely to be important for decision-making concerning indications for hepatectomy.

Some reports showed that technetium-99m-galactosyl human serum albumin (99mTc-GSA) liver scintigraphy was more useful than ICG15 retention rate in the assessment of histological hepatic damage ${ }^{[10,11]}$ and more effective in the prediction of complications and operative death in patients with hepatic disorders ${ }^{[12]}$. However, 99mTc-GSA scintigraphy using nuclides is performed only at a limited number of institutions and is not common worldwide.

\section{INDICATIONS FOR HEPATECTOMY}

Indicators for surgery other than hepatic reserve include tumor diameter, the number of tumors, presence of vascular invasion and extrahepatic metastasis. Looking at the stage classification, the EASL-EORTCguidelines $^{[2]}$ recommend hepatectomy as a treatment option for HCC patients at Barcelona Clinic Liver Cancer (BCLC) stage 0 or BCLC stage A and with normal portal blood pressure and bilirubin level. Transarterial chemoembolization (TACE) is recommended as a treatment for the patients at BCLC stage B [Figure 1]. However, studies showed the 5-year survival rate and perioperative mortality rate in HCC patients at BCLC stage B and undergoing hepatectomy were $30 \%$ to $57 \%$ and $2.6 \%$ to $5.4 \%$ respectively ${ }^{[13-16]}$, and the prognosis of the patients with solitary hepatocellular carcinoma and undergoing hepatectomy was much more favorable than those undergoing TACE. There are many surgeons/clinicians who believe that not all HCC patients at BCLC stage B should be excluded from an indication for hepatectomy.

In terms of the number of HCC tumors, a better prognosis was reported in patients with a solitary tumor than in patients with multiple tumors ${ }^{[17]}$. Hepatectomy was more useful than local ethanol injection treatment in patients with liver damage A or B under the general rules for the clinical and pathological study of primary liver cancer. The treatment plan may change depending on if the HCC tumor size is larger or smaller than $3 \mathrm{~cm}$. Hasegawa et al. ${ }^{[18]}$ reported that hepatectomy showed more favorable outcomes than radiofrequency ablation (RFA) in patients with a solitary tumor smaller than $3 \mathrm{~cm}$. As written above, hepatectomy is recommended as the first treatment option for patients with solitary HCC, and RFA is reported for patients with HCC smaller than $3 \mathrm{~cm}$ as the second treatment option equivalent to hepatectomy [Figure 2]. 


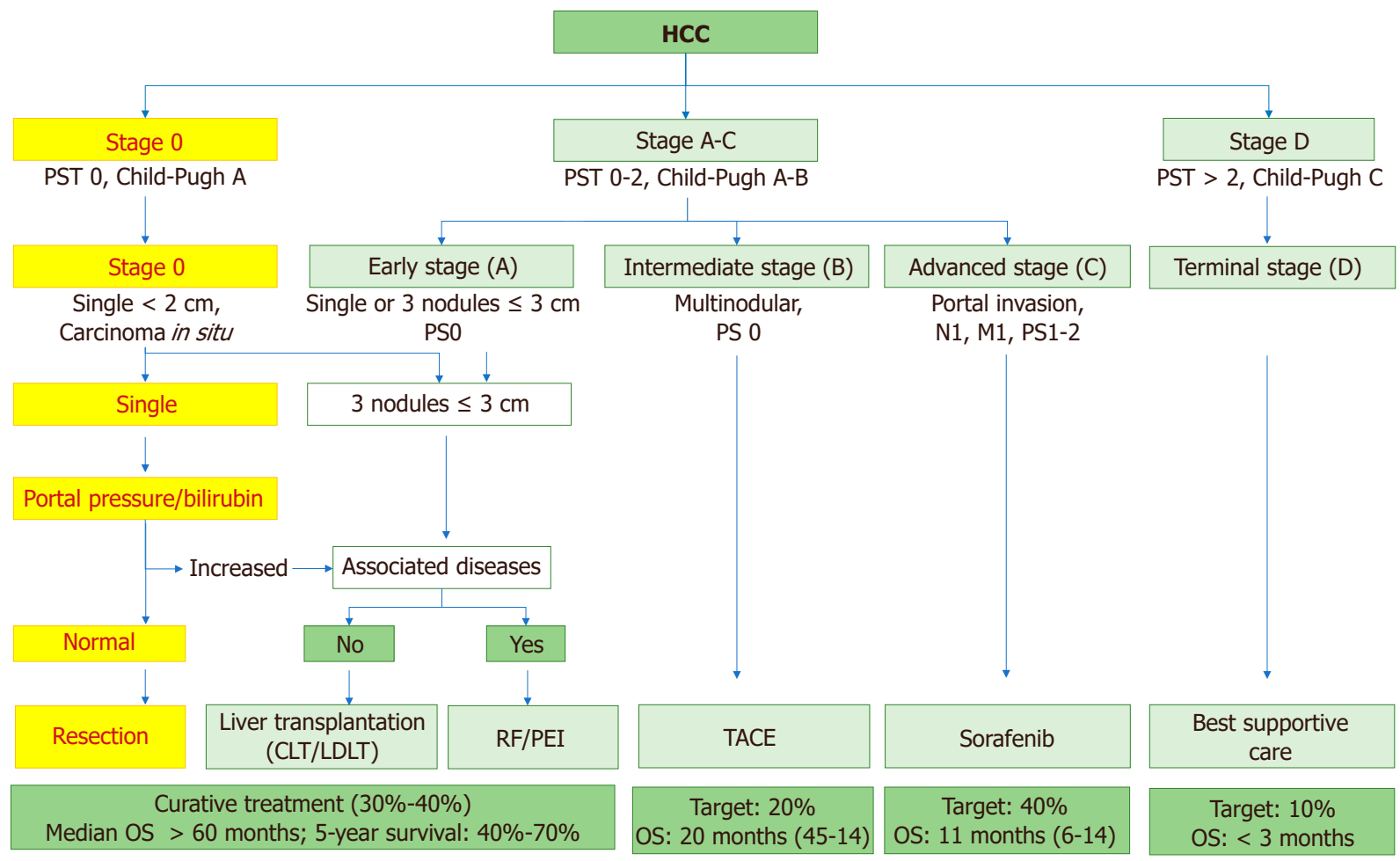

Figure 1. Updated BCLC staging system and treatment strategy: EASL-EORTC Clinical Practice Guidelines ${ }^{[2]}$. HCC: hepatocellular carcinoma; PST: performance status; CLT: cadaveric liver transplantation; LDLT: living donor liver transplantation; RF: radiofrequency; PEl: percutaneous ethanol injection; TACE: transcatheter arterial chemoembolization; OS: overall survival

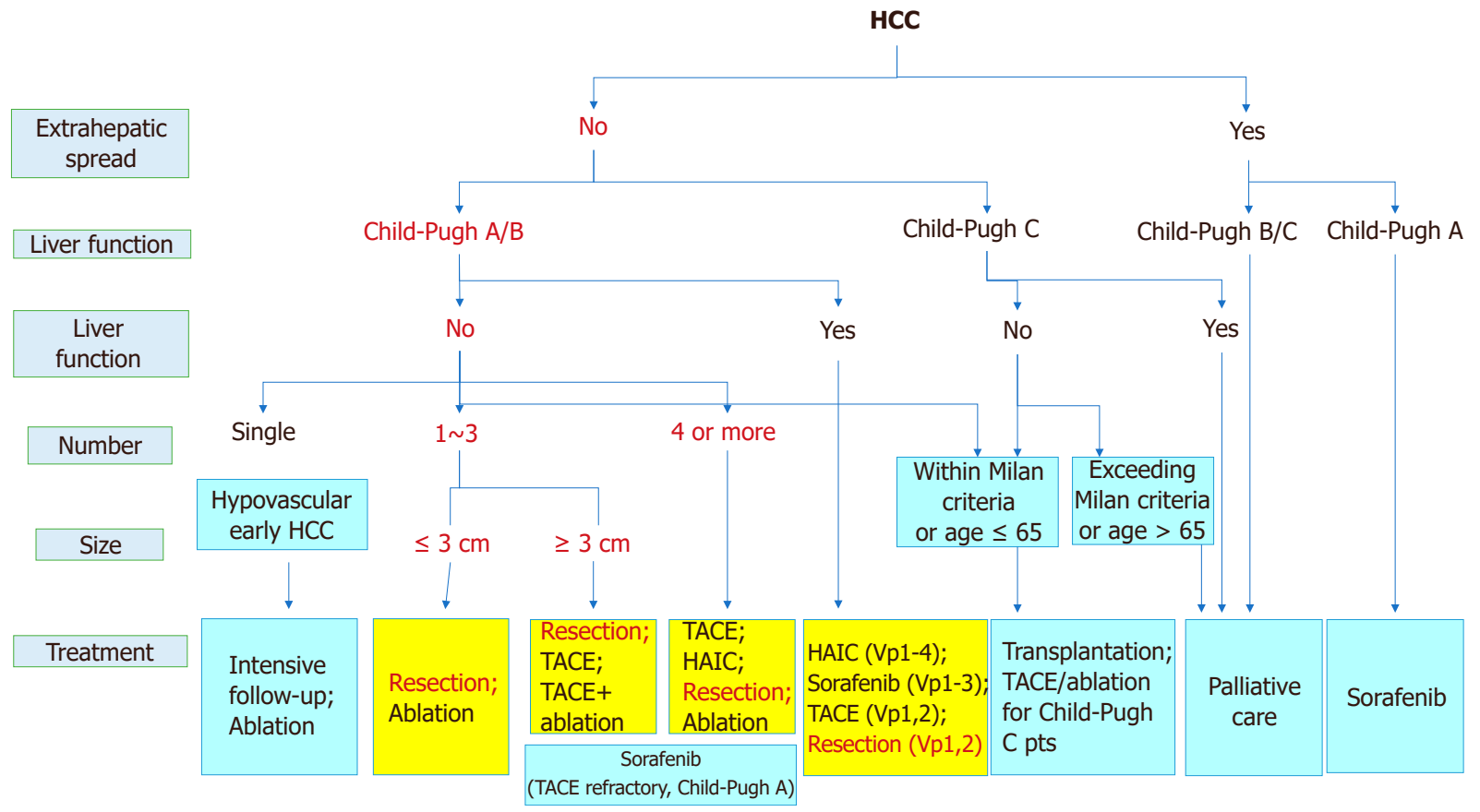

Figure 2. JSH-LCSGJ consensus-based treatment algorithm for hepatocellular carcinoma (HCC) revised in $2014^{[1]}$. TACE: transcatheter arterial chemoembolization; HAIC: hepatic arterial infusion chemotherapy; JSH: Japan Society of Hepatology; LCSGJ: Liver Cancer Study Group of Japan 
Hepatectomy or RFA is recommended for the patients with 2 or 3 tumors $3 \mathrm{~cm}$ or smaller, based on the data examined by Hasegawa et al. ${ }^{[18]}$. Huang et al. ${ }^{[19]}$ compared hepatectomy and RFA for HCC patients under the Milan criteria and showed a better survival rate in patients undergoing hepatectomy. However, since the patient characteristics in their study were very different from those in Japan, a randomized controlled trial (SURF trial, UMIN000001795) comparing hepatectomy and RFA in Japanese HCC patients under the Milan criteria has been conducted in Japan. The trial has not reported a high level of evidence for surgical resection and RFA in HCC patients with 4 or more tumors, and recommends transcatheter embolization/ chemoembolization (TAE/TACE) as the first treatment option and hepatic arterial infusion chemotherapy and molecular targeted drug therapy as the second treatment option for those patients.

\section{Indications for hepatectomy (vascular invasion)}

The indications for surgery for HCC with vascular invasion are described here. The 5-year survival rate for HCC patients with portal vein invasion and undergoing hepatectomy was found to be $1 \%$ to $38 \%$, which showed a survival benefit ${ }^{[20,21]}$. Kokudo et al. ${ }^{[21]}$ reported that the prognoses of patients with Child-Pugh score A and undergoing hepatectomy were strongly favorable and that hepatectomy was effective in patients with localized invasion in the first branch of the portal vein. TACE, molecular targeted drug therapy, and hepatic arterial infusion chemotherapy for HCC patients with vascular invasion were also reported ${ }^{[22-24]}$, but a consensus on these treatments has not yet been reached in Japan. Therefore, hepatectomy, embolization therapy, hepatic arterial infusion chemotherapy, and molecular targeted drug therapy are recommended equally at present in Japan as treatments for HCC patients with vascular invasion.

The AASLD ${ }^{[25]}$ guidelines suggest that adults with Child-Pugh class A cirrhosis and resectable $\mathrm{T} 1$ or T2 HCC undergo resection rather than radiofrequency ablation. These patients are indicated for resection. Most studies define patients with resectable HCC as those: (A) with one to three unilobar lesions, with an upper size limit of $5 \mathrm{~cm}$ for single lesions and $3 \mathrm{~cm}$ for more than one lesion; (B) without radiographic evidence of extrahepatic disease of macrovascular invasion; and (C) occurring in the setting of minimal or no portal hypertension and in the absence of synthetic dysfunction. It is different from Japanese guidelines. The Chinese guidelines ${ }^{[26]}$ similarly define general surgical indication for cases with less than three tumors. But, it is different from AASLD guidelines at the point about including resection of portal vein tumor thrombus (PVTT) and concomitant splenectomy for cases with portal hypertension.

In Europe and the US, the use of molecular targeted drug therapy is recommended for HCC patients with vascular invasion at BCLC stage $\mathrm{C}$.

\section{HEPATECTOMY PROCEDURE}

Since HCC is known to spread through veins into the liver, systematic removal of the tumor-bearing portal territory is advisable, if possible. Some recent literature has reported that patients undergoing systematic resection had better prognoses than those undergoing nonsystematic resection (segmental resection) ${ }^{[27-31]}$. However, many patients develop HCC in the background of chronic liver diseases, and some of them may not undergo systematic resection at present due to poor hepatic reserve. Therefore, the indication for surgery and the surgical procedure are often determined upon consideration of the balance between tumor conditions and liver function conditions. While systemic resection is anatomic resection of the tumor-bearing portal territory with consideration to HCC development through the portal vein, nonsystematic resection is resection of the tumor with some surgical margin regardless of the anatomy of the vessels. Some studies have reported that a comparison of surgical outcomes between systematic resection and nonsystematic resection showed no significant difference in cumulative survival rate and relapse-free survival rate ${ }^{[32-34]}$. It is recommended in Japan to choose either a small range of systematic resection or nonsystematic resection as 
reductive surgery, depending on hepatic function, for patients with small HCC ( $5 \mathrm{~cm}$ or smaller) and major resection of at least 2 segments for patients with large HCC.

The procedure for resection of the right hepatic vein at its root with preservation of the inferior right vein ${ }^{[35]}$, the procedure for systematic resection of the HCC-bearing portal territory with dye infusion under ultrasound guidance ${ }^{[36]}$, and the procedure for systematic resection of the identified tumor-bearing territory with transection of Glisson's sheath ${ }^{[37,38]}$ are reported as the surgical procedures preserving the liver parenchyma. The procedure for resection of segment 3 and 4 with preservation of segment $2^{[39]}$ is also included.

The surgical procedure for HCC in the caudate lobe generally removes the ventral liver parenchyma also, which has raised the question of impaired hepatic functions. Surgical procedures such as dorsal resection of the caudate lobe isolated and identified using the counterstaining technique $e^{[00,41]}$ and isolated resection of the caudate lobe after parenchymal transection along the middle hepatic vein ${ }^{[42]}$ currently have been designed.

Reports on laparoscopichepatectomy for HCC are increasinglately. It is reported that laparoscopichepatectomy is superior to open hepatectomy due to the magnifying effect of the area being operated on and allows less hemorrhage from the hepatic veins due to the hemorrhagic reduction effect of the pneumoperitoneum ${ }^{[43-45]}$. It is also reported that laparoscopic hepatectomy has a lower incidence of complications such as ascites than open hepatectomy ${ }^{[46-48]}$. Laparoscopic hepatectomy for HCC has been reported to have long-term outcomes equivalent to those of open hepatectomy and superior to radiofrequency ablation in local control for small HCC located at the liver surface. In Japan, laparoscopic hepatectomy is currently recommended based on the judgments of the International Consensus Conference on Laparoscopic Liver Resection that laparoscopic hepatectomy could be performed on patients with hepatic reserve sufficient to undergo open hepatectomy and is advisable for partial resection or lateral segmental resection for solitary tumor with a maximum diameter no more than $5 \mathrm{~cm}$ located in the anterior inferior segments (segments 2 to $6{ }^{[49]}$. In Europe and the US, some reports have described laparoscopic hepatectomy but have not made a clear recommendation for it. In any case, it is considered that laparoscopic hepatectomy should be done by a team with well-experienced surgeons and only at a well-equipped medical institution providing adequate intensive care during the perioperative period due to insufficient accumulation of evidence about safety in laparoscopic hepatectomy.

\section{PROGNOSIS OF PATIENTS UNDERGOING HEPATECTOMY}

The studies have reported that there was no significant difference in postoperative relapse rate between patients with resection margin of at least $1 \mathrm{~cm}$ and patients with resection margin of less than $1 \mathrm{~cm}^{[50-52]}$ and comparison of the prognosis in patients with resection margin of at least $5 \mathrm{~mm}$ and less than $5 \mathrm{~mm}$ also showed no significant difference in survival rate ${ }^{[53,54]}$. Based on these results, a minimum distance of resection margin is allowed for hepatectomy for HCC in Japan. In contrast, Hu et al.$^{[5]}$ reported that the prognosis was favorable in patients with Milan criteria-compliant HCC with resection margin of at least $1 \mathrm{~cm}$. Another study showed that patients with a resection margin of at least $2 \mathrm{~cm}$ had a more favorable prognosis than patients with a margin of $1 \mathrm{~cm}^{[56]}$. It is thought that the distance of the resection margin may affect prognosis.

Well-known predictors of poor prognosis after hepatectomy also include tumor diameter of at least $5 \mathrm{~cm}$, multiple tumors, no capsular formation, positive vascular invasion, impaired liver function, TNM classification stage 3 or 4 , and AFP level of at least $32 \mathrm{ng} / \mathrm{mL}^{[57,58]}$. Some research has indicated that tumor size is not a prognostic predicator $^{[59,60]}$.

Tumor markers such as PIVKA-II and AFP are reported as predictors of recurrence after hepatectomy for HCC. HCC patients with a thrombus in the main portal vein or the first branch of the portal vein are considered 
Table 1. The result of hepatic resection for HCC

\begin{tabular}{|c|c|c|c|c|}
\hline Author & HCC characteristics & 1-year OS (\%) & 3-year OS (\%) & 5-year OS (\%) \\
\hline Garancini et al. ${ }^{65]}$ & $\mathrm{BCLC} A / \mathrm{B}$ & $95 / 83.3$ & $61.1 / 50$ & $46.2 / 41.2$ \\
\hline Wu et al. ${ }^{[66)}$ & BCLC O-A & 95.9 & 85.3 & 67.6 \\
\hline Jiang et al. ${ }^{[67]}$ & BCLC A, multifocal & 96 & 71.7 & 36.3 \\
\hline Li et al. ${ }^{[68]}$ & $\mathrm{BCLC} A$ or $\mathrm{B}$, ruptured & 66.3 & 23.4 & 10.1 \\
\hline Xu et al. ${ }^{[69]}$ & BCLC B or C & 81.4 & 48.5 & 28.2 \\
\hline Wang et al. ${ }^{[70]}$ & Small tumors & 92.6 & 83.3 & 73 \\
\hline Shrager et al. ${ }^{[71]}$ & Large $\mathrm{HCC}(>10 \mathrm{~cm})$ & 57 & 30 & 19 \\
\hline Lee et $a{ }^{[72]}$ & Large $\mathrm{HCC}(>10 \mathrm{~cm})$ & 66 & 44 & 31 \\
\hline Shah et al. ${ }^{[73]}$ & Large HCC & 69 & 63 & 54 \\
\hline Pandey et $a / .{ }^{[74]}$ & Large $\mathrm{HCC}$ & 63 & 35 & 28.6 \\
\hline Ng et al..$^{[75]}$ & Large or multinodular & 74 & 50 & 39 \\
\hline Roayaie et al. ${ }^{[76]}$ & Macroscopic vascular invasion & 52 & 22 & 14 \\
\hline Pawilk et al. ${ }^{[20]}$ & Portal or hepatic vein invasion & 45 & 17 & 10 \\
\hline Ban et al. ${ }^{[77]}$ & Portal vein thrombosis & 70 & 37 & 22 \\
\hline Vitale et $a / .{ }^{[78]}$ & BCLC-C & 55 & 44 & 0 \\
\hline
\end{tabular}

HCC: hepatocellular carcinoma; OS: overall survival; BCLC: Barcelona Clinic Liver Cancer

to have a poor prognosis. The Glasgow Prognostic Score (GPS) is one of the important predictors and is believed to make the prognoses of HCC patients clearer ${ }^{[6]}$. In addition, some studies have shown that the preoperative neutrophil-lymph node ratio (NLR) is a predictor of poor prognosis ${ }^{[62]}$. Sarcopenia is also considered to be a predictor of poor prognosis ${ }^{[63]}$. Japanese study showed that patients with non-B non-C HCC had a better prognosis and a lower risk of recurrence than those with hepatitis $\mathrm{C}$ virus (HCV)-related HCC ${ }^{[64]}$.

We investigated the outcomes of HCC after hepatic resection ${ }^{[65-78]}$. There are no significant difference mortality of HCC patients between BCLC A and B [Table 1]. Garancini said that surgical treatment of HCC in BCLC stage B should not be considered contraindicated for such patients. HCC patients with vascular invasions had higher mortality rate than single large HCC. We should pay attention to vascular invasions more than tumor size for good surgical prognosis.

At last, we showed outcomes of hepatic resection in Japan. The Liver Cancer Study Group of Japan determined that the cumulative survival rate ${ }^{[64]}$ at all HCC stages was $90.2 \%$ at 1 year, $81.3 \%$ at 2 years, and $56.8 \%$ at 5 years. Looking at the 5 -year survival rate by tumor diameter, survival rate was $73.9 \%$ in patients with tumor size of less than $2 \mathrm{~cm}(n=4168), 63.1 \%$ in patients with tumor size of 2 to $3 \mathrm{~cm}(n=7212), 59.7 \%$ in patients with tumor size of 3 to $5 \mathrm{~cm}(n=6022)$, and $52.4 \%$ in patients with tumor size of 5 to $10 \mathrm{~cm}(n=3869)$. The 5-year survival rate of patients with tumor size of $10 \mathrm{~cm}$ and bigger was $45.4 \%$. Thus, patients with increasing tumor size have a worse prognosis. Looking at survival rate by the number of tumors, while the 1-year survival rate and the 5-year survival rate were $90 \%$ and $50 \%$ to $60 \%$ respectively in patients with one or two tumors, the 5-year survival rate declined to $37 \%$ in patients with more than three tumors [Table 2]. Looking at the 5 -year survival rate by stage, survival rate was $82.8 \%, 70 \%, 52 \%, 31 \%$, and $26.8 \%$ in patients at stage I, II, III, IVA, and IVB, respectively. However, the 5 -year survival rate has been increasing steadily in recent years. While it was $12.5 \%$ in the 1980 s, it steadily increased to $44 \%$ in the 2000 s.

The incision criteria are different in each guideline. But, expansion of criteria for resection is progressing. The survival rate of HCC after hepatic resection is expected to increase with better outcomes of hepatectomy in the future.

\section{CONCLUSION}

This paper has described indications for hepatectomy for patients with HCC through comparison of domestic guidelines with overseas guidelines, focusing on their differences. 
Table 2. Cumulative survival rates (\%) of hepatocellular carcinoma patients in Japan ${ }^{[61]}$ treated with hepatic resection

\begin{tabular}{|c|c|c|c|c|c|c|c|}
\hline \multirow{2}{*}{ Years } & & \multirow{2}{*}{ Number } & \multicolumn{5}{|c|}{ Cumulative survival rates (\%) } \\
\hline & & & 1 & 3 & 5 & 7 & 10 \\
\hline \multirow[t]{3}{*}{ Tumor number } & 1 & 16,531 & 93.7 & 80.8 & 67.0 & 54.7 & 39.0 \\
\hline & 2 & 3494 & 90.0 & 71.0 & 54.8 & 40.4 & 27.2 \\
\hline & $\geq 3$ & 2717 & 81.1 & 55.8 & 37.9 & 28.1 & 20.4 \\
\hline \multirow[t]{4}{*}{ Portal vein invasion } & VpO & 19,075 & 94.4 & 80.5 & 65.5 & 52.4 & 36.8 \\
\hline & Vp1 & 1908 & 84.9 & 62.4 & 48.2 & 39.0 & 28.9 \\
\hline & Vp2 & 714 & 69.1 & 42.2 & 29.2 & 22.5 & 17.3 \\
\hline & $\geq \mathrm{Vp} 3$ & 852 & 59.8 & 34.3 & 25.0 & 20.5 & 15.6 \\
\hline \multirow[t]{5}{*}{ TNM stage by LCSGJ } & 1 & 2339 & 97.8 & 90.0 & 74.3 & 61.4 & 42.5 \\
\hline & II & 9755 & 94.1 & 78.0 & 62.5 & 50.1 & 35.5 \\
\hline & III & 3902 & 85.6 & 61.8 & 43.5 & 33.5 & 23.3 \\
\hline & IVA & 1208 & 69.4 & 38.9 & 25.9 & 20.3 & 15.4 \\
\hline & IVB & 2118 & 56.5 & 28.0 & 18.7 & 14.5 & 14.5 \\
\hline
\end{tabular}

LCSGJ: Liver Cancer Study Group of Japan

\section{DECLARATIONS}

\section{Authors' contributions}

Mainly edited the manuscript: Yamaguchi S, Kosaka T

Qualified the manuscript: Eguchi S

Read and approved the manuscript: Yamaguchi S, Kosaka T, Eguchi S

\section{Availability of data and materials}

Not applicable.

\section{Financial support and sponsorship}

None.

\section{Conflicts of interest}

All authors declared that there are no conflicts of interest.

\section{Ethical approval and consent to participate}

Not applicable.

\section{Consent for publication}

Not applicable.

\section{Copyright}

(C) The Author(s) 2018.

\section{REFERENCES}

1. Kudo M, Matsui O, Izumi N, Iijima H, Kadoya M, Imai Y, Okusaka T, Miyayama S, Tsuchiya K, Ueshima K, Hiraoka A, Ikeda M, Ogasawara S, Yamashita T, Minami T, Yamakado K; Liver Cancer Study Group of Japan. JSH consensus-based clinical practice guidelines for the management of hepatocellular carcinoma: 2014 update by the Liver Cancer Study Group of Japan. Liver Cancer 2014;3:458-68.

2. European Association for the Study of the Liver, European Organization for Research and Treatment of Cancer. EASL-EORTC clinical practice guidelines: management of hepatocellular carcinoma. J Hepatol 2012;56:908-43.

3. Pugh RN, Murray-Lyon IM, Dawson JL, Pietroni MC, Williams R. Transection of the oesophagus for bleeding oesophageal varices. Br J Surg 1973;60:646-9.

4. Takada Y, Ito T, Ueda M, Sakamoto S, Haga H, Maetani Y, Ogawa K, OguraY, Oike F, Egawa H, Uemoto S. Living donor liver transplantation for patients with HCC exceeding the Milan criteria: a proposal of expanded criteria. Dig Dis 2007;25:299-302. 
5. Todo S, Fukukawa H; Japanese Study Group on Organ Transplantation. Living donor liver transplantation for adult patients with hepatocellular carcinoma: experience in Japan. Ann Surg 2004;240:451-9.

6. Liver Cancer Study Group of Japan. The general rules for the clinical and pathological study of primary liver cancer, 6th Japanese ed. Tokyo: Kanehara-Shuppan; 2015.

7. Fan ST, Lai EC, Lo CM, Ng IO, Wong J. Hospital mortality of major hepatectomy for hepatocellular carcinoma associated with cirrhosis. Arch Surg 1995;130:198-203.

8. Yamanaka N, Okamoto E, Oriyama T, Fujimoto J, Furukawa K, Kawamura E, Tanaka T, Tomoda F. A prediction scoring system to select the surgical treatment of liver cancer. Further refinement based on 10 years of use. Ann Surg 1994;219:342-6.

9. Miyagawa S, Makuuchi M, Kawasaki S, Kakazu T. Criteria for safe hepatic resection. Am J Surg 1995;169:589-94.

10. Kwon AH, Ha-Kawa SK, Uetsuji S, Inoue S, Matsui Y, Kamiyama Y. Preoperative determination of the surgical procedure for hepatectomy using technetium-99m-galactosyl human serum albumin (99mTc-GSA) liver scintigraphy. Hepatology 1997;25:426-9.

11. Kamohara Y, Takatsuki M, Hidaka M, Soyama A, Kanematsu T, Eguchi S. 99mTc-Galactosyl sialyl albumin (GSA) scintigram adjusts hepatic resection range in ICG based estimation. Hepatogastroenterology 2011;58:2058-61.

12. Hayashi H, Beppu T, Okabe H, Kuroki H, Nakagawa S, Imai K, Nitta H, Chikamoto A, Ishiko T, Baba H. Functional assessment versus conventional volumetric assessment in the prediction of operative outcomes after major hepatectomy. Surgery 2015;157:20-6.

13. Lin CT, Hsu KF, Chen TW, Yu JC, Chan DC, Yu CY, Hsieh TY, Fan HL, Kuo SM, Shung KP, Hsieh CB. Comparing hepatic resection and transarterial chemoembolization for Barcelona Clinic Liver Cancer (BCLC) stage B hepatocellular carcionoma: change for treatment of choice? World J Surg 2010;34:2155-61.

14. Wang JH, Changchien CS, Hu TH, Lee CM, Kee KM, Lin CY, Chen CL, Chen TY, Huang YJ, Lu SN. The efficacy of treatment schedules according to Barcelona Clinic Liver Cancer staging for hepatocellular carcinoma - survival analysis of 3892 patients. Eur J Cancer 2008;44:1000-6.

15. Zhong JH, Ke Y, Gong WF, Xiang BD, Ma L, Ye XP, Peng T, Xie GS, Li LQ. Hepatic resection associated with good survival for selected patients with intermediate and advanced-stage hepatocellular carcinoma. Ann Surg 2014;260:329-40.

16. Torzilli G, Belghiti J, Kokudo N, Takayama T, Capussotti L, Nuzzo G, Vauthey JN, Choti MA, De Santibanes E, Donadon M, Morenghi E, Makuuchi M. A snapshot of the effective indications and results of surgery for hepatocellular carcinoma in tertiary referral centers: is it adherent to the EASL/AASLD recommendations?: an observational study of the HCC East-West study group. Ann Surg 2013;257:929-37.

17. Ho MC, Huang GT, Tsang YM, Lee PH, Chen DS, Sheu JC, Chen CH. Liver resection improves the survival of patients with multiple hepatocellular carcinomas. Ann Surg Oncol 2009;16:848-55.

18. Hasegawa K, Kokudo N, Makuuchi M, Izumi N, Ichida T, Kudo M, Ku Y, Sakamoto M, Nakashima O, Matsui O, Matsuyama Y. Comparison of resection and ablation for hepatocellular carcionoma: a cohort study based on a Japanese nationwide survey. J Hepatol 2013;58:724-9.

19. Huang J, Yan L, Cheng Z, Wu H, Du L, Wang J, Xu Y, Zeng Y. A randomized trial comparing radiofrequency ablation and surgical resection for HCC conforming to the Milan criteria. Ann Surg 2010;252:903-12.

20. Pawlik TM, Poon RT, Abdalla EK, Ikai I, Nagormey DM, Belghiti J, Kianmanesh R, Ng IO, Curley SA, Yamaoka Y, Lauwers GY, Vauthey JN. Hepatectomy for hepatocellular carcinoma with major portal or hepatic vein invasion: results of a multicenter study. Surgery 2005;137:403-10.

21. Kokudo T, Hasegawa K, Matsuyama Y, Takayama T, Izumi N, Kadoya M, Kudo M, Ku Y, Sakamoto M, Nakashima O, Kaneko S, Kokudo N; Liver Cancer Study Group of Japan. Survival benefit of liver resection for hepatocellular carcinoma associated with portal vein invasion. J Hepatol 2016;65:938-943.

22. Luo J, Guo RP, Lai EC, Zhang YJ, Lau WY, Chen MS, Shi M. Transarterial chemoembolization for unresectable hepatocellular carcinoma with portal vein tumor thrombosis: a prospective comparative study. Ann Surg Oncol 2011;18:413-20.

23. Bruix J, Raoul JL, Sherman M, Mazzaferro V, Bolondi L, Craxi A, Galle PR, Santoro A, Beaugrand M, Sangiovanni A, Porta C, Gerken G, Marrero JA, Nadel A, Shan M, Moscovici M, Voliotis D, Llovet JM. Efficacy and safety of sorafenib in patients with advanced hepatocellular carcinoma: subanalyses of a phase III trial. J Hepatol 2012;57:821-9.

24. Nouso K, Miyahara K, Uchida D, Kuwaki K, Izumi N, Omata M, Ichida T, Kudo M, Ku Y, Kokudo N, Sakamoto M, Nakashima O, Takayama T, Matsui O, Matsuyama Y, Yamamoto K; Liver Cancer Study Group of Japan. Effect of hepatic arterial infusion chemotherapy of 5-fluorouracil and cisplatin for advanced hepatocellular carcinoma in the Nationwide Survey of Primary Liver Cancer in Japan. Br J Cancer 2013;109:1904-7.

25. Heimbach JK, Kulik LM, Finn RS, Sirlin CB, Abecassis MM, Roberts LR, Zhu AX, Murad MH, Marrero JA. AASLD guidelines for the treatment of hepatocellular carcinoma. Hepatology 2018;67:358-80.

26. Qin S; Primary Liver Cancer Diagnosis and Treatment Expert Panel of the Chinese Ministry of Health. Guidelines on the diagnosis and treatment of primary liver cancer (2011 edition). Chin Clin Oncol 2012;1:10.

27. Zhou Y, Xu D, Wu L, Li B. Meta-analysis of anatomic resection versus nonanatomic resection for hepatocellular carcinoma. Langenbecks Arch Surg 2011;396:1109-17.

28. Cucchetti A, Cescon M, Ercolani G, Bigonzi E, Torzilli G, Pinna AD. A comprehensive meta-regression analysis on outcome of anatomic resection versus nonanatomic resection for hepatocellular carcinoma. Ann Surg Oncol 2012;19:3697-705.

29. Eguchi S, Kanematsu T, Arii S, Okazaki M, Okita K, Omata M, Ikai I, Kudo M, Kojiro M, Makuuchi M, Monden M, Matsuyama Y, Nakamura Y, Takayasu K; Liver Cancer Study Group of Japan. Comparison of outcomes between an anatomical subsegmentectomy and a non-anatomical minor hepatectomy for single hepatocellular carcinomas based on a Japanese nationwide survey. Surgery 
2008;143:469-75.

30. Shindoh J, Makuuchi M, Matsuyama Y, Mise Y, Arita J, Sakamoto Y, Hasegawa K, Kokudo N. Complete removal of the tumor-bearing portal territory decreases local tumor recurrence and improves disease-specific survival of patients with hepatocellular carcinoma. J Hepatol 2016;64:594-600.

31. Lim C, Ishizawa T, Miyata A, Mise Y, Sakamoto Y, Hasegawa K, Sugawara Y, Kokudo N. Surgical indications and procedures for resection of hepatic malignancies confined to segment VII. Ann Surg 2016;263:529-37.

32. Cucchetti A, Qiao GL, Cescon M, Li J, Xia Y, Ercolani G, Shen F, Pinna AD. Anatomic versus nonanatomic resection in cirrhotic patients. Surgery 2014;155:512-21.

33. Marubashi S, Gotoh K, Akita H, Takahashi H, Ito Y, Yano M, Ishikawa O, Sakon M. Anatomical versus non-anatomical resection for hepatocellular carcinoma. Br J Surg 2015;102:776-84.

34. Hirokawa F, Kubo S, Nagano H, Nakai H, Kaibori M, Hayashi M, Takemura S, Wada H, Nakata Y, Matsui K, Ishizaki M, Uchiyama K. Do patients with small solitary hepatocellular carcinomas without macroscopically vascular invasion require anatomic resection? Propensity score analysis. Surgery 2015;157:27-36.

35. Makuuchi M, Hasegawa H, Yamazaki S, Takayasu K. Four new hepatectomy procedures for resection of the right hepatic vein and preservation of the inferior right hepatic vein. Surg Gynecol Obstet 1987;164:68-72.

36. Makuuchi M, Hasegawa H, Yamazaki S. Ultrasonically guided subsegmentectomy. Surg Gynecol Obstet 1985;161:346-50

37. Takasaki K, Kobayashi S, Tanaka S, Saito A, Yamamoto M, Hanyu F. Highly anatomically systematized hepatic resection with Glissonean sheath code transection at the hepatic hilus. Int Surg 1990;75:73-7.

38. Yamamoto M, Katagiri S, Ariizumi S, Kotera Y, Takahashi Y. Glissonean pedicle transection method for liver surgery (with video). J Hepatobiliary Pancreat Sci 2012;19:3-8.

39. Kawasaki S, Makuuchi M, HaradaH, Takayama T, Kosuge T. A new alternative hepatectomy method for resection of segments 3 and 4 of the liver. Surg Gynecol Obstet 1992;175:267-9.

40. Midorikawa Y, Takayama T. Caudate lobectomy (segmentectomy 1) (with video). J Hepatobiliary Pancreat Sci 2012;19:48-53.

41. Takayama T, Tanaka T, Higaki T, Katou K, Teshima Y, Makuuchi M. High dorsal resection of the liver. J Am Coll Surg 1994;179:72-5.

42. Yamamoto J, Kosuge T, Shimada K, Yamasaki S, Takayama T, Makuuchi M. Anterior transhepatic approach for isolated resection of the caudate lobe of the liver. World J Surg 1999;23:97-101.

43. Yin Z, Fan X, Ye H, Yin D, Wang J. Short- and long-term outcomes after laparoscopic and open hepatectomy for hepatocellular carcinoma: a global systematic review and meta-analysis. Ann Surg Oncol 2013;20:1203-15.

44. Xiong JJ, Altaf K, Javed MA, Huang W, Mukherjee R, Mai G, Sutton R, Liu XB, Hu WM. Meta-analysis of laparoscopic vs open liver resection for hepatocellular carcinoma. World J Gastroenterol 2012;18:6657-68.

45. Takahara T, Wakabayashi G, Beppu T, Aihara A, Hasegawa K, Gotohda N, Hatano E, Tanahashi Y, Mizuguchi T, Kamiyama T, Ikeda T, Tanaka S, Taniai N, Baba H, Tanabe M, Kokudo N, Konishi M, Uemoto S, Sugioka A, Hirata K, Taketomi A, Maehara Y, Kubo S, Uchida E, Miyata H, Nakamura M, Kaneko H, Yamaue H, Miyazaki M, Takada T. Long-term and perioperative outcomes of laparoscopic versus open liver resection for hepatocellular carcinoma with propensity score matching: a multi-institutional Japanese study. J Hepatobiliary Pancreat Sci 2015;22:721-7.

46. MoriseZ, Ciria R, Cherqui D, Chen KH, Belli G, Wakabayashi G. Can we expand the indications for laparoscopic liver resection? A systematic review and meta-analysis of laparoscopic liver resection for patients with hepatocellular carcinoma and chronic liver disease. J Hepatobiliary Pancreat Sci 2015;22:342-52.

47. Twaji A, Pucher PH, Sodergren MH, Gall T, Darzi A, Jiao LR. Laparoscopic vs open approach to resection of hepatocellular carcinoma in patients with known cirrhosis: systematic review and meta-analysis. World J Gastroenterol 2014;20:8274-81.

48. Kanazawa A, Tsukamoto T, Shimizu S, Kodai S, Yamazoe S, Yamamoto S, Kubo S. Impact of laparoscopic liver resection for hepatocellular carcinoma with F4-liver cirrhosis. Surg Endosc 2013;27:2592-7.

49. Wakabayashi G, Cherqui D, Geller DA, Buell JF, Kaneko H, Han HS, Asbun H, O'Rourke N, Tanabe M, Koffron AJ, Tsung A, Soubrane O, Machado MA, Gayet B, Troisi RI, Pessaux P, Van Dam RM, Scatton O, Abu Hilal M, Belli G, Kwon CH, Edwin B, Choi GH, Aldrighetti LA, Cai X, Cleary S, Chen KH, Schön MR, Sugioka A, Tang CN, Herman P, Pekolj J, Chen XP, Dagher I, Jarnagin W, Yamamoto M, Strong R, Jagannath P, Lo CM, Clavien PA, Kokudo N, Barkun J, Strasberg SM. Recommendations for laparoscopic liver resection: a report from the second international consensus conference held in Morioka. Ann Surg 2015;261:619-29.

50. Tang YH, Wen TF, Chen X. Resection margin in hepatectomy for hepatocellular carcinoma: a systematic review. Hepatogastroenterology 2012;59:1393-7.

51. Poon RT, Fan ST, Ng IO, Wong J. Significance of resection margin in hepatectomy for hepatocellular carcinoma: a critical reappraisal. Ann Surg 2000;231:544-51.

52. Arii S, Tanaka J, Yamazoe Y, Minematsu S, Morino T, Fujita K, Maetani S, Tobe T. Predictive factors for intrahepatic recurrence of hepatocellular carcinoma after partial hepatectomy. Cancer 1992;69:913-9.

53. Kawasaki S, Makuuchi M, Miyagawa S, Kakazu T, Hayashi K, Kasai H, Miwa S, Hui AM, Nishimaki K. Results of hepatic resection for hepatocellular carcinoma. World J Surg 1995;19:31-4.

54. Kosuge T, Makuuchi M, Takayama T, Yamamoto J, Shimada K, Yamasaki S. Long-term results after resection of hepatocellular carcinoma: experience of 480 cases. Hepatogastroenterology 1993;40:328-32.

55. Hu W, Pang X, Guo W, Wu L, Zhang B. Relationship of different surgical margins with recurrence-free survival in patients with 
hepatocellular carcinoma. Int J Clin Exp Pathol 2015;8:3404-9.

56. Shi M, Guo RP, Lin XJ, Zhang YQ, Chen MS, Zhang CQ, Lau WY, Li JQ. Partial hepatectomy with wide versus narrow resection margin for solitary hepatocellular carcinoma: a prospective randomized trial. Ann Surg 2007;245:36-43.

57. Poon RT, Ng IO, Fan ST, Lai EC, Lo CM, Liu CL, Wong J. Clinicopathologic features of long-term survivors and disease-free survivors after resection of hepatocellular carcinoma: a study of a prospective cohort. J Clin Oncol 2001;19:3037-44.

58. Imamura H, Matsuyama Y, Tanaka E, Ohkubo T, Hasegawa K, Miyagawa S, Sugawara Y, Minagawa M, Takayama T, Kawasaki S, Makuuchi M. Risk factors contributing to early and late phase intrahepatic recurrence of hepatocellular carcinoma after hepatectomy. J Hepatol 2003;38:200-7.

59. Yang LY, Fang F, Ou DP, Wu W, Zeng ZJ, Wu F. Solitary large hepatocellular carcinoma: a specific subtype of hepatocellular carcinoma with good outcome after hepatic resection. Ann Surg 2009;249:118-23.

60. Franco D, Capussotti L, Smadja C, Bouzari H, Meakins J, Kemeny F, Grange D, Dellepiane M. Resection of hepatocellular carcinomas. Results in 72 European patients with cirrhosis. Gastroenterology 1990;98:733-8.

61. Ishizuka M, Kubota K, Kita J, Shimoda M, Kato M, Sawada T. Impact of an inflammation-based prognostic system on patients undergoing surgery for hepatocellular carcinoma: a retrospective study of 398 Japanese patients. Am J Surg 2012;203:101-6.

62. Mano Y, Shirabe K, Yamashita Y, Harimoto N, Tsujita E, Takeishi K, Aishima S, Ikegami T, Yoshizumi T, Yamanaka T, Maehara Y. Preoperative neutrophil-to-lymphocyte ratio is a predictor of survival after hepatectomy for hepatocellular carcinoma: a retrospective analysis. Ann Surg 2013;258:301-5.

63. Voron T, Tselikas L, Pietrasz D, Pigneur F, Laurent A, Compagnon P, Salloum C, Luciani A, Azoulay D. Sarcopenia impacts on shortand long-term results of hepatectomy for hepatocellular carcinoma. Ann Surg 2015;261:1173-83.

64. Utsunomiya T, Shimada M, Kudo M, Ichida T Matsui O, Izumi N, Matsuyama Y, Sakamoto M, Nakashima O, Ku Y, Takayama T, Kokudo N; Liver Cancer Study Group of Japan. A comparison of the surgical outcomes among patients with HBV-positive, HCVpositive, and non-B non-C hepatocellular carcinoma: a nationwide study of 11950 patients. Ann Surg 2015;261:513-20.

65. Garancini M, Nespoli S, Romano F, Uggeri F, Degrate L, Okolicsanyi S, Gianotti L. Surgical management of hepatocellular carcinoma within and beyond BCLC indications in a middle volume center. J Visc Surg 2018;17:S1878-86.

66. Wu F, Wang L, Wu J, Rong W, Tian F, Bi C. Analysis of risk factors of recurrence in patients with BCLC 0-A hepatocellular carcinoma after surgical resection. Zhonghua Yi Xue Za Zhi 2015;95:1747-50.

67. Jiang L, Yan L, Wen T, Li B, Zeng Y, Yang J, Wang W, Xu M, Wu H. Comparison of outcomes of hepatic resection and radiofrequency ablation for hepatocellular carcinoma patients with multifocal tumors meeting the Barcelona-Clinic Liver Cancer stage A classification. J Am Coll Surg 2015;221:951-61.

68. Li J, Huang L, Liu CF, Cao J, Yan JJ, Xu F, Wu MC, Yan YQ. Risk factors and surgical outcomes for spontaneous rupture of BCLC stages A and B hepatocellular carcinoma: a case-control study. World J Gastoenterol 2014;20:9121-7.

69. Xu W, Guo R, Xu G, Sun L, Hu D, Xu H, Yang H, Sang X, Lu X, Mao Y. Management of intrahepatic recurrence after resection for hepatocellular carcinoma exceeding the barcelona clinic liver cancer criteria. Oncotarget 2017;8:110406-14.

70. Wang K, Eguchi S, Hidaka M, Jin T, Soyama A, Kuroki T, Huang M, Wu L, Zou S, Shao J. Comparison of the outcomes of hepatocellular carcinoma after hepatectomy between two regional medical centers in China and Japan. Asian J Surg 2017;40:380-8.

71. Shrager B, Jibara Ga, Tabrizian P, Schwartz ME, Labow DM, Hiotis S. Resection of large hepatocellular carcinoma ( $\geq 10 \mathrm{~cm})$ : a unique western perspective. J Surg Oncol 2013;107:111-7.

72. Lee SG, Hwang S, Jung JP, Lee YJ, Kim KH, Ahn CS. Outcome of patients with huge hepatocellular carcinoma after primary resection and treatment of recurrent lesions. Br J Surg 2007;94:320-6.

73. Shah SA, Wei AC, Cleary SP, Yang I, Gilvray ID, Gallinger S, Grant DR, Greig PD. Prognosis and results after resection of very large (>or=10 cm) hepatocellular carcinoma. J Gastrointest Surg 2007;11:589-95.

74. Pandey D, Lee KH, Wai CT, Wagholikar G, Tan KC. Long term outcome and prognostic factors for large hepatocellular carcinoma (10 $\mathrm{cm}$ or more) after surgical resection. Ann Surg Oncol 2007;14:2817-23.

75. Ng KK, Vauthey JN, Pawlik TM, Lauwers GY, Regimbeau JM, Belghiti J, Ikai I, Yamaoka Y, Curley SA, Nagorney DM, Ng IO, Fan ST, Poon RT; International Cooperative Study Group on Hepatocellular Carcinoma. Is hepatic resection for large or multinodular hepatocellular carcinoma justified? Results from a multi-institutional database. Ann Surg Oncol 2005;12:364-73.

76. Roayaie S, Jivara G, Taouli B, Schwartz M. Resection of hepatocellular carcinoma with macroscopic vascular invasion. Ann Surg Oncol 2013;20:3754-60.

77. Ban D, Shimada K, Yamamoto Y, Nara S, Esaki M, Sakamoto Y, Kosuge T. Efficacy of a hepatectomy and a tumor thrombectomy for hepatocellular carcinoma with tumor thrombus extending to the main portal vein. J Gastrointest Surg 2009;13:1921-8.

78. Vitale A, Saracino E, Boccagni P, Brolese A, D’Amico F, Gringeri E, Neri D, Srsen N, Valmasoni M, Zanus G, Carraro A, Violi P, Pauletto A, Bassi D, Polacco M, Burra P, Farinati F, Feltracco P, Romano A, D’Amico DF, Cillo U. Validation of the BCLC prognostic system in surgical hepatocellular cancer patients. Transplant Proc 2009;41:1260-3. 